\title{
Henrietta Rose-Innes in conversation with Gail Fincham
}

GF: You've recently returned from the UK, where you went for your PhD viva examination. This turned on your submission of your latest (fifth) novel. Can you say something about this novel: what it's called, how it relates to your previous four novels?

HRI: Thank you! Yes, I've recently completed a manuscript entitled Stone Plant, which should be published in 2020.

I see the new novel as the third part of a very loose trilogy of environmentally themed novels, along with Nineveh and Green Lion. Each of these books examines the human relationship with the non-human world in different ways: Nineveh deals with our urban coexistence with the multitudes of organisms around us, and how we need to negotiate unpredictable changes in these complex systems. The focus is on the small and non-mammalian, represented here by a swarm of mysterious, pestilential beetles. I think it's a book about the irrepressibility of life, and how it thrives in unexpected ways, whether we welcome it or not.

Green Lion, on the other hand, is a bleaker book, looking at the other side of these interactions with the non-human. Its major animal figure is the last surviving individual of an extinct lion species, and it deals with loss and mortality. It looks at how we are bleeding the earth of our co-species, fetishising them and turning the spaces we share with them into sterile wastelands - the loss and the loneliness of that predicament.

In Stone Plant, I wanted to return to a more hopeful vision: set in a slightly future or alternative Cape Town (as are the other two books), the focus is on the plant world. A central being in the story is an ancient plant that finds ways to survive a drought-scarred world, and revive and propagate, by manipulating the human characters around it. It's a more ambitious novel than I've attempted before: it expands the cast of characters not only to the vegetable kingdom, but even to inanimate objects and the long dead. I want the book to speak about the resilience of life, and how survival strategies may be playing out on such a slow time-scale - the long cycles of vegetable life, even of geological time-that perhaps we cannot perceive them.

GF: Did you grow up in an ecologically sensitive household? Do you have animals? (cat named Sekhmet, dog named Soldier?)

HRI: My parents loved plants and the outdoors. My mother especially was a lifelong gardener, and also a painter of very beautiful, detailed botanical watercolours. (Some of her works are in the botanical art collection at Kew-we are very proud of that.) We often walked on Table Mountain, or went on family holidays to national parks. So yes, there was always a strong affinity for wilderness. I've recently moved to the South Peninsula, where I live surrounded by wildlife; but I actually think being in Norwich, far removed from this kind of landscape, also made me dwell on it more. The distance might have affected my writing more strongly than my current immersive environment will. Cape Town is very present in Stone Plant-but it is a somewhat 'other' Cape Town, dreamlike, having perhaps drifted over from a nearby parallel universe-which I think is partly a result of the book having been composed in another hemisphere.

I do have cats, but none named Sekhmet, although they are all of course incarnations of the Egyptian lion-headed goddess of bloodshed and war. (My interest in ancient cultures, evident in the epigraphs in Green Lion, is also part of my mother's legacy; she studied archaeology as a young woman, and for good or ill I spent my childhood leafing through dusty old texts with titles like The Glory That Was Rome.)

Gail Fincham is Emeritus Professor at the University of Cape Town, Cape Town, South Africa. Her research explores the relationship between Europe and Africa and intersections between modernist, post-modernist, and post-colonial fiction.

Email: gfincham@afrihost.co.za

(iD https://orcid.org/0000-0001-6472-601X

Henrietta Rose-Innes is a writer of novels and short stories. She is published in the UK by Aardvark Bureau/Gallic Books and in South Africa by Penguin Random House.

Email: aitchri@gmail.com

(D) https://orcid.org/0000-0002-3467-6792

DOI: https://doi.org/10.17159/2309-9070/tvl.v.56i2.6769 
GF: The book covers of your four novels are striking, yet all so different. How did their design come about? Are you happy with all of them?

HRI: They are spaced out over many years and several publishers. My very first cover, Shark's Egg for Kwela Books, was kindly designed by a friend of mine, which at the time I didn't realise wasn't the way these things are always done. My last two novels, Nineveh and Green Lion, have each had a number of different editions now, in different countries with different markets, and I always find the variations fascinating. I really love the ominous, Ballardian cover of the American Nineveh (Unnamed Press), although it doesn't evoke the local landscape; and I appreciate the elegant style of my covers for my French-language editions (Editions Zoe). I'm not too protective of the covers-I'm very happy for a clever designer to take it out of my hands and come back with something astonishing that I never could have imagined for myself. My latest book of short stories, Animalia Paradoxa, which has just recently been published in Norwich by Boiler House Press, has a striking abstract cover-I never would have associated my work with that kind of minimalist elegance, but it works beautifully. As mentioned, I am hoping that Nineveh, Green Lion, and Stone Plant will be viewed as an informal trilogy, and I'm pleased that both my UK publisher and my local publisher have now coordinated the covers so that the first two books, and I'm hoping the third, all have matching covers by the same brilliant local designer (for design company publicide).

\section{GF: Any idea of where your next novel might take you?}

HRI: I haven't got an inkling of the next one yet. But once Stone Plant is off my hands, I am keen to start writing more short stories. I would like to get together a new collection of completely new stories. I have a feeling they will be a little weirder and more removed from day-to-day reality than what I've written to date; maybe speculative fiction, or adjacent to it. This seems to be the direction my stories are going in.

GF: How does your recent experience of doctoral study in the UK compare with your earlier international residencies? I'm thinking of the relationship between having space for uninterrupted writing and the stimulus of working with other writers?

HRI: I've been very fortunate in the number of residencies I've been able to attend around the world. The greatest gift is to have time to write away from workaday cares and duties. The $\mathrm{PhD}$ was a very different experience, however, because it offered quite the opposite to that kind of removal. At the University of East Anglia (UEA), I felt thrust into the heart of a fervently active literary world. I was able to have fruitful discussions on my novel-in-progress with my very supportive supervisor, the writer Jean McNeil, and I engaged with many other inspiring authors, at the university and beyond. There's a tradition of creative thought and writing on ecology and the urban landscape in the UK, which I was glad to tap into. I also made publishing connections. I believe my presence in the UK was crucial to my getting published there, as was the excellent reputation of the UEA creative writing programme. Those connections are maintained long after the degree, and indeed led directly to the production of Animalia Paradoxa-Boiler House Press is based at UEA.

GF: The move from the first two novels (which have no epigraphs) to the last two (where Nineveh has several epigraphs prefacing the novel and Green Lion has epigraphs prefacing each of its eight sections): do these epigraphs position the reader differently from before?

HRI: In Nineveh the epigraph was meant to establish a deep historical context for the novel by evoking some of the very oldest cities, Nineveh and Ur. I was hoping to suggest that the rise and fall of the grand housing estate in the novel is a minor eddy in the ancient, endlessly repeating cycle of human construction and destruction. The epigraph lends a universal dimension to a story that otherwise can feel quite narrowly focused on the idiosyncrasies of the local.

In Green Lion, the epigraphs also gesture towards times past. Many of them refer to ancient, mystical animal figures from other eras, gods, and ghosts. In part, this was meant to contrast the vulnerable bodies of real animals threatened by human acts, with the idealised, untouchable, powerful totems that humans choose to preserve and revere in their place.

In both books, the epigraphs act as a quiet counterpart to the more immediate narrative, pulling the reader out of the story briefly for a moment of oblique contemplation. 
GF: Your first novel, Shark's Egg, plays out in relation to the Cape's seas, and is strikingly visual. Because in a number of epiphanies, like that of the Aquarium, we see Anna seeing (where 'seeing' is emotional and cognitive as well as physical), we are confident that, faced with the challenge of the last chapter, "Sink or Swim", Anna will swim. You have described this novel as your most autobiographical.

HRI: As is the case with many debut novels, Shark's Egg is probably the book that has the most autobiographical elements of all my novels. While Anna's story is not exactly mine, the settings in which she finds herself are ones that I was very familiar with in my teens and twenties. I did spend a lot of time on the mountain, and I have always been drawn to certain institutional spaces like aquariums, galleries, museums-spaces that allow one to engage with an expansive world while remaining a solitary observer. This chimes with my sense of myself as a novelist. These places are also very nostalgic for me and once again summon up my mother-she was the artist at Cape Town's natural history museum when she was younger.

GF: Williams makes the point that after Shark's Egg the sensorium you employ is as much acoustic as visual. Can you comment on this change of direction in your subsequent novels?

HRI: I do think I am more a sensual than a cerebral writer; my primary impulse is often a visual image. But I think that each of my novels is attuned to a different sensory mode-especially since I've been writing about animals. In Nineveh, for example, there is a lot of emphasis on sound - the scuttling of insects, frogs peeping in the swamp. In Green Lion, on the other hand, there's much more attention paid to smell, befitting a book focused on a large mammalian predator. In Stone Plant, taste comes into play. Focussing on these secondary senses, apart from being enjoyably sensual, is a way to distance myself a little from the human prejudice towards the visual; an attempt to access the non-human experience (of course an impossible task).

GF: Williams (436) also remarks on your background in archaeology and paleoanthropology, seeing these as informing your second novel, The Rock Alphabet. To me, this is your most mysterious and enigmatic text, since one is left with many questions that cannot be answered. Does your archaeological/anthropological background point you towards the historical and cultural mysteries of Bushman paintings in the Cederberg?

HRI: I studied archaeology as an undergrad and some of my happiest memories of being a student involved the annual field trips to map rock paintings in the Cederberg. Sometimes the paint colours are very subtle and faded, but once you get your eye in you can't stop spotting them on the rocks, and it's like a whole dimension of hidden meaning in the landscape is revealed. In some parts of those mountains, the paintings are so plentiful they overlay the landscape like a secret text in a vanished language. Very compelling for a writer.

GF: Your phrase "like a secret text in a vanished language" recalls Stephen Watson's observation that the Bushmen and women of the Cederberg were "people so far removed from us that in their conception of life there was no such thing as the inorganic or otherwise dead matter" (302). Perhaps this profound ontological difference between the San worldview, signalled in their paintings, and our own, accounts for the mystery that hangs over your text in The Rock Alphabet.

HRI: I do think that the book is about history's essential unknowability: the inscrutability of the past and of the dead, and the need to retain a necessary humility about what we can never know. I am not so bold as to make any definitive statements about the worldview of the rock artists.

GF: Your third novel, Nineveh, has received widely differing critical responses. My question to you is simply whether in this novel you see urban expansion and ecological survival as compatible?

HRI: I think part of what I wanted to convey in Nineveh is that cities and 'nature' are inextricably mixed up and tangled in each other: there is no separating them into pure and distinct systems, and it's not necessarily a question of one surviving at the expense of others. Urban ecologies will persist, although they may not take the forms that we might imagine or desire, and the balance between their elements—rats and weeds, bricks and mortar —is constantly in flux.

GF: Loren Kruger's reading of Nineveh echoes what you have just said in that she foregrounds this urban/natural entanglement, seeing the novel as about "the interpenetration of the developed and the wild, 'culture' and 'nature', the urban street and the apparently bare earth" (17). Shane Graham however reads Nineveh more pessimistically: as "about invasion and infiltration, entropy and dis- 
integration" (76). But in your interview with Riach you remark: "Nineveh is a hopeful book. It's about acknowledging and even celebrating all varieties of habitation of our shared urban space, human and non-human, even if it comes to forms that are unpredictable, uncontrolled, and unwelcome" (9). Is the key to Nineveh's 'hopefulness', then, the human and non-human capacity for adaptation?

HRI: Entropy and entanglement are ever-present conditions of the universe, and I don't view them as negative forces. I think one way to countenance the future (and survive to see it) in these times of eco-catastrophe is to find ways to engage with our environment as it is and as it could be, rather than with a conception of pristine nature as it maybe never was.

GF: Fiona Moolla remarks that "African ecocriticism cannot be established upon conceptions of nature that present themselves as universal. African ecocriticisms furthermore reveal that relationships with land are always social and political" (20). Can you say something about how Nineveh's relationship with land is both social and political?

HRI: There is no way to write about land ownership in South Africa, in Cape Town, without our history of violent dispossession being the clear subtext; and any book dealing with contested land is by definition political. Throughout Nineveh, there are references to the layers of occupation and use and re-use of the land on which the book plays out. The premise of the book (and in fact of Green Lion) is a rejection of the enforced regulation of urban space and enforced segregation of its inhabitants-the sorry history of South Africa from colonial conquest through apartheid and into the present.

GF: Moving now to your fourth novel, Green Lion, you remark, in the "Concrete Fragments" interview with Graham Riach, that Green Lion is a bleaker book than Nineveh: "With its theme of animal extinctions, it shows the enforced emptying out of a landscape by the forces of environmental destruction; this is a sterile, unromantic emptiness, that leaves the characters more isolated than before" (9). But could I go back to what Riach says in his article on the politics of space? There he links your narrative strategies to "a literary negotiation of the unresolved issue of post-apartheid spatial distribution". He states that your use of "imperfect spatial cadences" leads to "ambiguity and open-endedness" as "formal solutions buckle under the weight of societal complexit[ies] they try to resolve" (2). Might these "imperfect spatial cadences" permit the reader of Green Lion to harbour some hope that, despite environmental devastation, beyond the fence erected on Table Mountain to imprison the people of Cape Town, some animals may still survive?

HRI: Green Lion itself does not allow for much of that kind of ambiguity. What it leaves us with is the sense that much of our natural world will linger on only as phantoms or fetishes in the human psyche. The "formal solutions" that are critiqued in the book, such as the conservationist impulse to fence off the land, do fail. But I would like to think this book will be read in conjunction with Nineveh and Stone Plant, both of which offer a counterpoint: a vision of messier, unregulatable systems that allow for the resurgence of resilient living systems.

\section{GF: You've said that the writing of Green Lion helped you mourn the death of your mother. Do you want to say more about this?}

HRI: While on one level the book is about the loss of species, on another it deals with our human fear of death, and the impossibility of bringing what we love back from oblivion. It was only after I had finished writing it that I understood that - of course - it was about my own bereavement, written as it was in the aftermath of my mother's death. Whether it helped, I can't say.

GF: You comment that in your latest, still unpublished book, Stone Plant, you are "turning back towards compression and stylisation" because "deep down, the transformative hallucinatory quality of language is what [you] value most" (Riach, "Concrete Fragments" 3). Can you elaborate?

HRI: I value a destabilising sense of estrangement in writing; among other things, it is one way to approach writing about the non-human. It's one reason why science fiction has always had value for me. The short stories I've been writing recently, and the new novel, edge towards the speculative, without delving into outright fantasy. I've often said that the space I'm interested in exploring, in classic fantasy terms, is not exactly Narnia, and perhaps not even The Wood Between the Worlds, but perhaps the wardrobe: that space of possibility, where we have the first inkling that a break in perceived reality is imminent. Those are the moments that offer the most magical tension and potential for revelation and escape —-for me as a reader, and also as a writer. 
GF: Rob Nixon foregrounds the opposition between the politics of ownership of place and the experience of displacement in postcolonial writing. Huggan and Tiffin similarly draw attention to "the tension between ownership and belonging in a variety of colonial and postcolonial contexts: contexts marked, for the most part, by a direct or indirect engagement with often devastating experiences of dispossession and loss" (85). Can you comment on the relevance of this opposition or tension to your fiction?

HRI: Of course, dispossession is the backdrop to every South African story, particularly one that deals with contested land. My protagonists (e.g. Katya in Nineveh; Con in Green Lion) often feel positively dislocated from the spaces that they move through - they are certainly not the inheritors of this landscape. I try to resist reductionist ideas of 'belonging', though; that land is more naturally inhabited by some than by others. Every character's relationship with the land is contingent, ephemeral, and subject to change. In Stone Plant, for example, the plant has occupied the central location in the story for centuries, but this primeval inhabitant is ultimately revealed to be transient, and able to respond to shifts in the universe by upping roots and propagating to more favourable climes.

GF: Finally, could I attempt to summarise some of what we've been discussing? From the first line of your first novel ("It's a strange day to come walking by the sea"), your preoccupation with the environment is central. This environmentalism is augmented by visual, auditory and sensory devices which dramatize your protagonists' development. But your ecological emphasis is never limited either to the environment or to the psychological growth of your characters. It is always linked to the political context of your writing, as your remarks on land ownership in South Africa in this interview attest. (Perhaps this demonstrates the multi-layered ideological implications of an ecological vision). The increasing narratological complexity in the trajectory of your novels is accompanied by increasing political complexity: the thematics of both Nineveh and Green Lion are multiply refracted through their use of epigraphs. What are the problems and challenges that this narrative process demands in orchestrating your readers' responses?

HRI: I'm pleased that increasing complexity is evident in the books. I do try to keep grappling with new problems, technically and thematically, and each time it feels like my range broadens. Stone Plant involves choreographing the timelines of multiple beings, not all human (or even animate), and some of them very old: an attempt to decentre the human view, perhaps, to expand the politics. It's challenging, in part because a large canvas is not the easiest mode for me-my default focus is on the compelling detail or moment, which more easily translates into the short story form. I've wrestled with this manuscript longer than any other, and I'm hoping that, ultimately, the plant and I both win.

\section{Works Cited}

Graham, Shane. "The Entropy of Built Things: Postapartheid Anxiety and the Production of Space in Henrietta Rose-Innes' Nineveh and Lauren Beukes' Zoo City." Safundi: The Journal of South African and American Studies vol. 16, no. 1, 2015, pp. 64-77. DOI: https://doi.org/10.1080/17533171.2014.983309.

Huggan, Graham \& Helen Tiffin. Postcolonial Ecocriticism: Literature, Animals, Environment. Routledge, 2010.

Kruger, Loren. "Cape Town and the sustainable city in the writing of Henrietta Rose-Innes." Journal of Urban Cultural Studies vol. 2, no. 1-2, 2019, pp. 15-33. DOI: https://doi.org/10.1386/jucs.2.1-2.15 1.

Moolla, Fiona, ed. Natures of Africa: Ecocriticism and Animal Studies in Contemporary Cultural Forms. Wits U P, 2016.

Nixon, Rob. Slow Violence and the Environmentalism of the Poor. Harvard U P, 20ll. https://www.jstor.org/stable/j.ctt2jbsgw.

Riach, Graham K. "Henrietta Rose-Innes and the Politics of Space." Journal of Commonwealth Literature, pp. 1-16. DOI: https:// doi.org/10.1177/0021989418780937. ."Concrete Fragments': An Interview with Henrietta Rose-Innes." Journal of Commonwealth Literature pp. 1-10. DOI: https://doi.org/10.1177/0021989418777021.

Rose-Innes, Henrietta. Animalia Paradoxa. Boiler House, 2019 Green Lion. Umuzi, 2015

Nineveh. Umuzi, 2011.

The Rock Alphabet. Kwela, 2004.

Shark's Egg. Kwela, 2000

Watson, Stephen. The Music in the Ice: On Writers, Writings and Other Things. Penguin, 2010. Williams, Daniel. "Life Among the Vermin: Nineveh and Ecological Relocation." Studies in the Novel vol. 50, no. 3, 2018, pp. 419-40. DOI: https://doi.org/10.1353/ sdn.2018.0028. 